\title{
Spectrophotometric Determination and Cloud Point Extraction of Cefixime Drugs in Pure form and Pharmaceutical Preparation
}

\author{
SAADIYAH A.DHAHIR and J. NOOR \\ Department of Chemistry, College of Science for Women, University of Baghdad \\ sadiataher@yahoo.com
}

Received 12 August 2018 / Accepted 3 September 2018

\begin{abstract}
A simple, rapid, accurate, sensitive and eco friendly method has been developed for the quantitative determination of cefixime(CFX) in pure form and pharmaceutical preparations by using a combination of cloud point extraction with UV-Visible absorption spectrophotometric method. Analytical applications of complexation with metal ions by reacting cefixime (CFX) with copper(II) and iron(III) to form chelate complexes under limited experimental conditions. The method based to dissolved CFX in $0.1 \mathrm{M} \mathrm{NaOH}, 10 \%$ (v/v) triton $\mathrm{x}-114$ and mixed with $\left(1000 \mu \mathrm{gmL}^{-1}\right)$ copper(II) or $\left(1000 \mu \mathrm{gmL}^{-1}\right)$ iron(III). The formation of CFX-Cu(II) complex at $\mathrm{pH} 13$ and wavelength 827 while the complex of CFX-Fe(III) was formatted at $\mathrm{pH} 11$ and wavelength at $439 \mathrm{~nm}$. The complexes of CFX-Cu(II) and CFX-Fe(III) obey Beer's Law in the range 10-130 and $10-160 \mu \mathrm{g} / \mathrm{mL}$ respectively. LOD and LOQ values for these complexes were $1.6906 \mu \mathrm{g} / \mathrm{mL}$ and $5.6355 \mu \mathrm{g} / \mathrm{mL}$ and LOQ values were $1.58655 \mu \mathrm{g} / \mathrm{mL}$ and $5.2887 \mu \mathrm{g} / \mathrm{mL}$ respectively. Method was validated and successfully applied to drug formulations like syrup infusion marketed in Amman and cefixime capsules marketed in Iraq. The results of analysis have been validated statistically by recovery studies and were found satisfactory.
\end{abstract}

Keywords: Antibiotic, Cefixime, Copper ion, Iron ion, Cloud point extraction

\section{Introduction}

Antibiotics are the chemotherapeutic agents that kill or inhibit the growth of microorganisms. This chemical agent is used to treat disease by destroying pathogenic microorganisms or inhibiting their growth at concentration low enough to avoid undesirable damage to the host. Antibiotics are drugs preparations which contain some chemical substances that are produced by microorganisms and by chemical synthesis. These substances at very low concentrations are known to totally destroy or partially inhibit microorganisms. Antibiotics have wide spread application in the treatment of bacterial disease ${ }^{1}$ cefixime is the only oral third generation cephalosporin with a broad spectrum of antimicrobial effect on Haemophilus influenzae, Moraxella catarrhalis, Neisseria gonorrheae, Escherichia coli and Klebsiella resistant to ampicillin, other oral cephalosporins and trimethoprim-sulfamethoxazole. This characteristic 
of cefixime permits its use in urinary and respiratory tract infections ${ }^{2}$ cefixime $(\mathrm{CFX})((6 R, 7 R)$ 7-[(Z)-2-(2-amino-4-thiazolyl)-2-(carboxy-methoxyimino) acetamido]-8-oxo-3 vinyl-5-thia-1azabicyclo-[4,2,0]-oct-2-ene-2-carboxylic acid), is a compound with potent mucolytic activity, for which it is used as an expectorant and broncho secretolytic in therapeutics ${ }^{3}$. The structures of drugs are shown in (Figure 1).

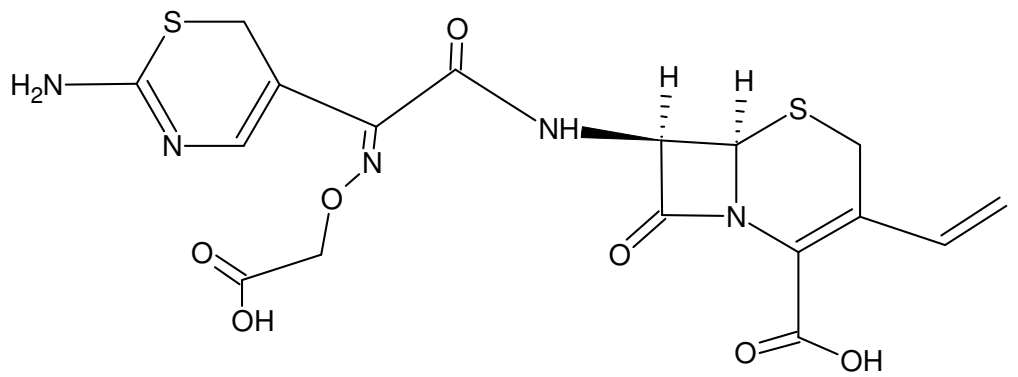

Formula $\left(\mathrm{C}_{16} \mathrm{H}_{15} \mathrm{~N}_{5} \mathrm{O}_{7} \mathrm{~S}_{2}\right)$, Mol.Wt, (453.452 g/mol)

Figure 1. The structure of cefixime ${ }^{4}$

It is third generation cephalosporin antibiotic. It is under the category of $\beta$-lactam antibiotics/cell wall inhibitor. It acts by inhibiting an enzyme transpeptidase, involved in the building of bacterial cell walls. It is used in lower respiratory tract infections. It is helpful in acute urinary tract infections, biliary tract infections, sinusitis, acute otitis media, peptic ulcer and many more ${ }^{4}$. It is used to treat or prevent infections that are proven or strongly suspected to be caused by bacteria. One of the major problems with this drug is its very poor solubility in biological fluids that results into poor bioavailability after oral administration. It shows erratic dissolution problem in gastric and intestinal fluid due to its poor water solubility. Rate of absorption and/or extent of bioavailability for such insoluble drugs are controlled by rate of dissolution in gastrointestinal fluids ${ }^{5}$ which describes a liquid chromatographic method for its assay in bulk form. In order to assure the quantity of cefixime in dosage forms, several methods have been reported which include liquid chromatography-mass spectrometry ${ }^{6}$, high performance liquid chromatography ${ }^{7-10}$, high performance thin layer chromatography ${ }^{11,12}$, derivative spectrophotometry ${ }^{13}$, voltammetry ${ }^{14}$, and capillary electrophoresis ${ }^{15}$. The cloud point procedure (CPE) is based on the following phenomenon: an aqueous solution of some surfactant becomes turbid and separates into two isotropic phases if some condition such as temperature or pressure is changed or if an appropriate substance is added to the solution ${ }^{16}$.

The aim of present work was to develop simple, economical, rapid, precise and accurate and eco friendly method for determination of CFX drug by using cloud point extraction.

\section{Experimental}

UV-Visible recording spectrophotometer SHIMADZU, Double beam UV-Vis, model UV1800 made (Japan) with a response time of $0.1 \mathrm{~s}$ was used for spectrophotomatric determination A quartz cell of $1 \mathrm{~mL}$ internal volume and $1 \mathrm{~cm}$ path length was used for absorbance measurements. Hotplate Stirrer (Hotplate stirrer Model L-81 Labincobv). Electric Balance (Sartorius, 4 digitals, made in Germany). OVEN (Memmert, maximum temperature 250, made in western Germany). Water Bath (A thermostat water Bath, model Unitemp) Centrifuge (Triup International corp, TRIU 800 Centrifuge, made in Korea). PHmeter (model BP 3001). 


\section{Drug and Materials}

The chemicals used for this work are of high purity and used as received. Distilled water was used in the preparation of all solutions and for final rinsing of glass wares. A pure grade of cefixime was obtained from drug industries and Midical Appliance (SID) Samarra/ Iraq. A stock solution of $1000 \mu \mathrm{gmL}^{-1}$ or $\left(2.205 \times 10^{-3} \mathrm{M}\right)$ for the drug cefix was prepared by dissolving $0.1 \mathrm{~g}$ in minimum amount of water and diluted to mark with water in a $100 \mathrm{~mL}$ volumetric flask. $0.1 \mathrm{M}$ of $\mathrm{NaOH}(\mathrm{BDH}, \mathrm{UK})$ was prepared from concentrated solution $(1 \mathrm{M})$ by transferring $10 \mathrm{~mL}$ into100 mL volumetric flask and diluted to mark with water. A stock solutions $\left(1000 \mu \mathrm{gmL}^{-1}\right)$ of copper ion(II)and iron ion(III) (95.5\%, Sigma, USA) were prepared by dissolving $3.8 \mathrm{~g}$ of copper ion and $2.9 \mathrm{~g}$ of iron ion in $1000 \mathrm{~mL}$ volumetric class. Triton $\mathrm{x}-114$ (purity $>99.9 \%$ ), was purchased from AMRESCO LLC (Solon, USA). A $10 \%(\mathrm{v} / \mathrm{v})$ of Triton $\mathrm{x}-114$ was prepared by diluting $10 \mathrm{~mL}$ with water in a $100 \mathrm{~mL}$ volumetric flask.

\section{Recommended CPE procedure for cefix drug}

Aliquots $10 \mathrm{~mL}$ of a solution containing known amount of cefixime drug was mixed with $\mathrm{Cu}^{+2}$ or $\mathrm{Fe}^{+3}$ ions. Then $\mathrm{pH}$ was adjusted by using $0.1 \mathrm{M} \mathrm{NaOH}$ and $10 \%(\mathrm{v} / \mathrm{v})$ triton $\mathrm{x}-114$. The mixture was shaken for $1 \mathrm{~min}$ and left to stand in a thermo-stated bath at $50{ }^{\circ} \mathrm{C}$, for $20 \mathrm{~min}$. Separation of the phases was achieved by centrifugation at $3000 \mathrm{rpm}$ for $10 \mathrm{~min}$, with stirring at $5{ }^{\circ} \mathrm{C}$ in ice bath the remaining of micellar phase was dissolved by ethanol, the measurements of absorbance of the complexes were followed by UV-Visible spectrophotometer with used $1.0 \mathrm{~cm}$ quartz cell at $\lambda_{\max }$ equal to $827 \mathrm{~nm}$ for $\mathrm{CFX}-\mathrm{Cu}$ (II) complex and $439 \mathrm{~nm}$ for CFX-Fe(III) complex against blank which was prepared in the same way but without drug.

\section{Preparation of pharmaceutical samples}

Two types of pharmaceuticals for CFX namely capsules and syrup were obtained from the drugstores in Iraq and Amman. The powder of five capsules was mixed, homogenized and the content of one capsule $(0.5339 \mathrm{~g})$ which equivalent to $533.9 \mathrm{mg}$ of active drug was dissolved in sufficient amount of water with continuous shaking and filtered. The filtrate solution was transferred into a $100 \mathrm{~mL}$ volumetric flask and diluted to mark with water. Solution contains $4000 \mu \mathrm{gmL}^{-1}$ of CFX from which $1000 \mu \mathrm{gmL}^{-1}$ was prepared by dilution. $25 \mathrm{~mL}$ containing different concentrations of the prepared sample solution were transferred to centrifugal tubes and each solution followed the recommended CPE procedure for cefix and the content of drug was measured spectrophotometrically at $\lambda_{\max }$ of 439 and $827 \mathrm{~nm}$. The pharmaceuticals for syrup as each $(5 \mathrm{~mL})$ from drug contains $(100 \mathrm{mg})$ cefixime. Solution is prepared by taking $(5 \mathrm{~mL})$ from syrup and dissolved in ethanol then solution is filtered and dilute in $(100 \mathrm{~mL})$ volumetric flask by distilled water, so that it gives $\left(1000 \mu \mathrm{gmL}^{-1}\right)$ from cefix. The same procedure is applied for syrup, CPE procedure for cefix and the content of drug was measured spectrophotometrically at $\lambda_{\max }$ of $439 \mathrm{~nm}$ and $827 \mathrm{~nm}$.

\section{Statistical analysis}

Excel 2010 (Microsoft officer) was employed to carry out all statistical calculations.

\section{Results and Discussion}

\section{Absorption spectra}

In an attempt to ascertain the occurrence of reaction between two complexes in the reaction system, an absorption maximum at $827 \mathrm{~nm}$ (Figure 2) and $439 \mathrm{~nm}$ (Figure 3) which was 
adopted of CPE for the drug. The absorption spectrum of the complex product formed was also recorded against the corresponding metal blank between 200 to $1100 \mathrm{~nm}$ before obtaining optimum conditions according to the recommended CPE procedure using a SHIMADZU, double beam UV-Vis, model UV-1800 with $1.0 \mathrm{~cm}$ quartz cell. It was observed that the absorption maximum of the colored product complex of cefix in $1.0 \mathrm{~mL}$ of $10 \%$ TX-114 occurred $827 \mathrm{~nm}$, giving the molar absorptivities of $3 \times 10^{3} \mathrm{~L}_{\mathrm{mol}}{ }^{-1} \cdot \mathrm{cm}^{-1}$ for cefix drug with copper and $1.9 \times 10^{2} \mathrm{~L} . \mathrm{mol}^{-1} . \mathrm{cm}^{-1}$ for cefix drug with iron respectively. Thus the wavelength maximum at $827 \mathrm{~nm}$ and $439 \mathrm{~nm}$ for the cefix complex product was used throughout this study for ppm amounts.

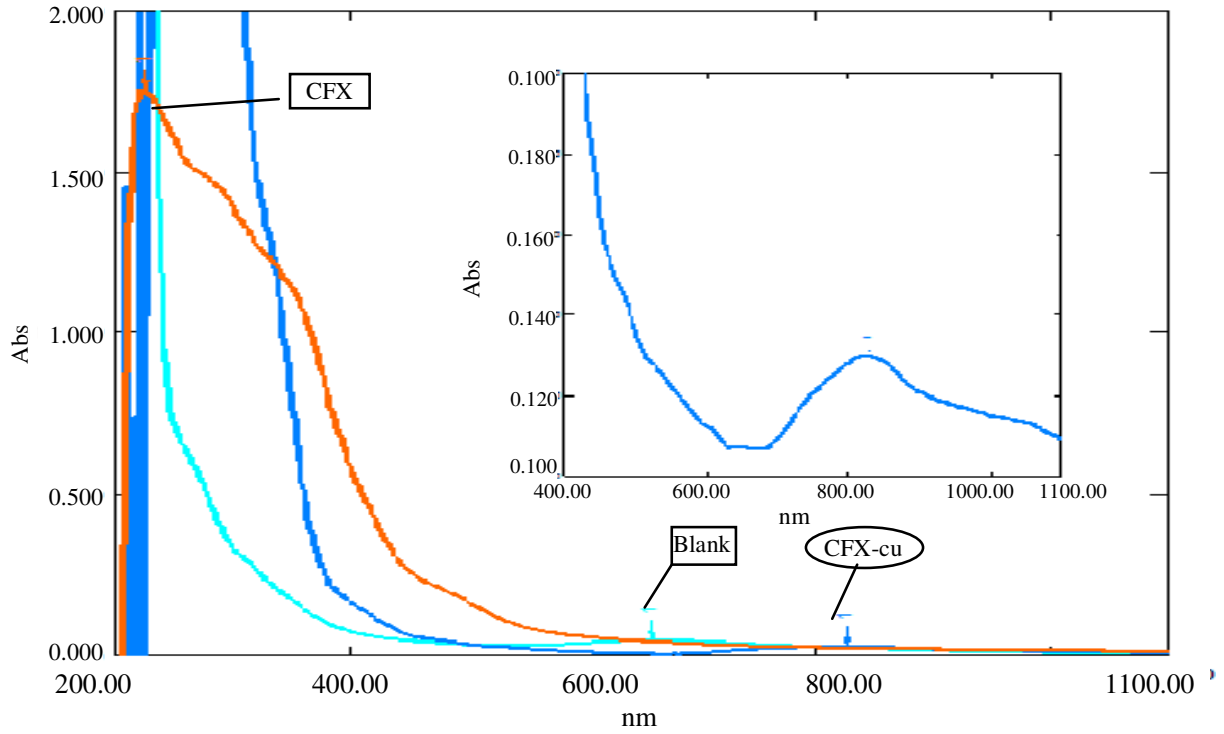

Figure 2. The absorption spectrum of the $\mathrm{CFX}-\mathrm{Cu}(\mathrm{II})$ complex

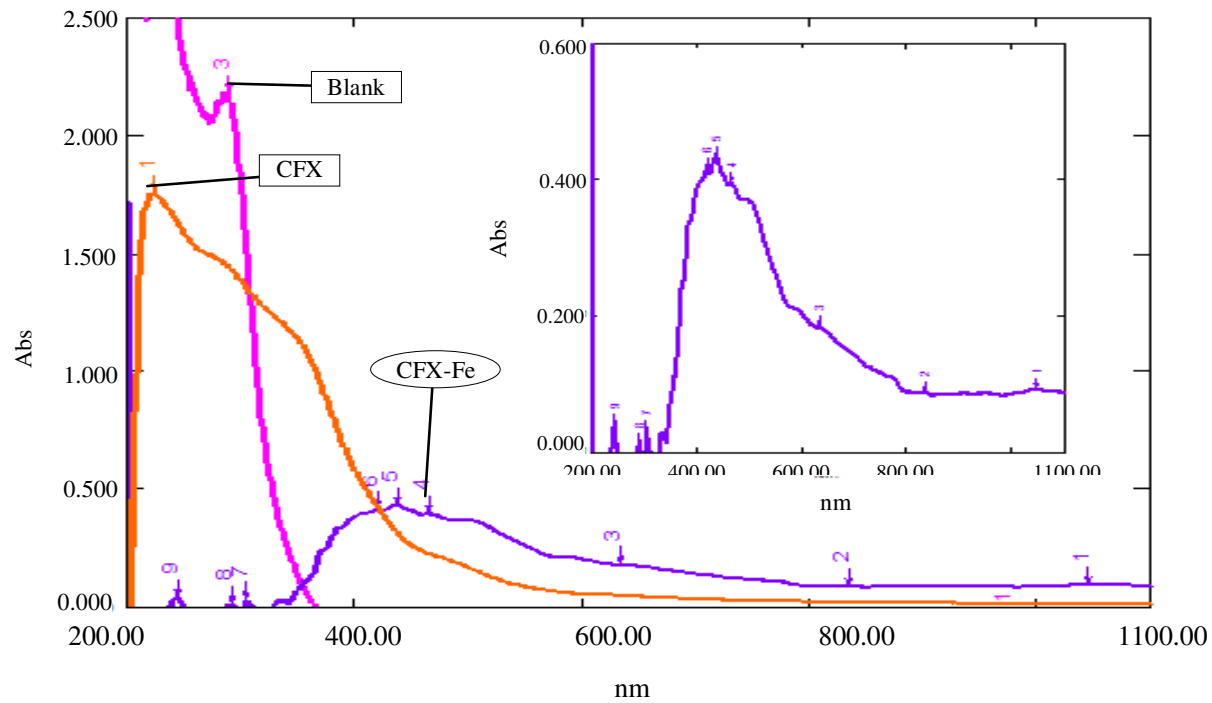

Figure 3. The absorption spectrum of the CFX-Fe(III) complex 


\section{Optimization of CPE methodology}

A group of experiments has been conducted to study the effect of several variables that affect the extraction efficiency of the $\mathrm{CPE}$ and maximize the sensitivity of the detection system for drug under study using a classical optimization. The variables such as the concentration of metal ion, best of $\mathrm{pH}$, best of buffer, best of volume buffer, triton $\mathrm{x}-114$ amount, equilibration temperature and incubation time.

\section{Effect of metal ions concentration}

The effect of iron and cupric ion concentrations upon the absorbance values of the extracted complexes using $1000 \mu \mathrm{g} / \mathrm{mL}$ of drug solution. The optimum concentration of the metal ions that gave maximum absorbance was $100 \mu \mathrm{g} / \mathrm{mL}$ of the optimum concentration of $\mathrm{Cu}$ (II) and $\mathrm{Fe}(\mathrm{III})$ ions were for complex. The absorbance is measured and the absorbance results are shown in Figure 4.

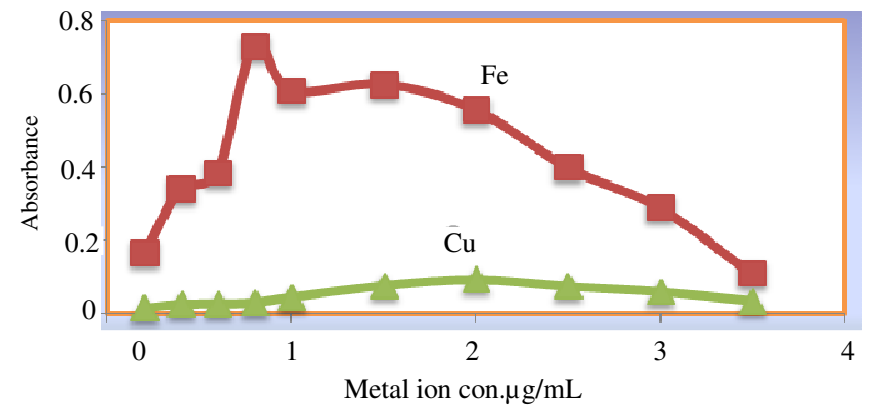

Figure 4. Effect of optimum concentration $\mathrm{Cu}(\mathrm{II})$ and $\mathrm{Fe}(\mathrm{III})$ ion concentration on absorbance of drug metal complexes

\section{Effect of $p H$}

The $\mathrm{pH}$ plays a unique role on metal ligand formation and subsequent extraction and is proved to be a main parameter for $\mathrm{CPE}^{17}$, to find the best acidic function of the ion extraction process different value of $\mathrm{pH} \mathrm{1-14}$. The results are shown in Figure 5, the best separation was achieved at $\mathrm{pH}=11$ for $\mathrm{Fe}(\mathrm{III})$ and $\mathrm{pH}=13$ for $\mathrm{Cu}(\mathrm{II})$. Show the value of absorbance intensity for the complexes drug- $\mathrm{Cu}$ and drug- $\mathrm{Fe}$ against the value of $\mathrm{pH}$, the best values of $\mathrm{pH}$ recorded for the highest absorbance values were plotting of the absorbance values versus the value of $\mathrm{pH}$ is shown in Figure 5.

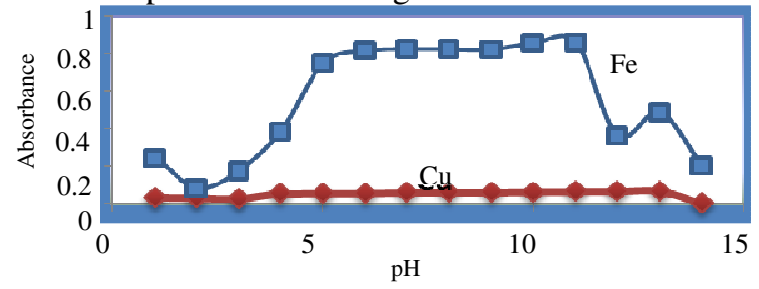

Figure 5. pH effect on the absorbance of drug- $\mathrm{Cu}(\mathrm{II})$ and drug- $\mathrm{Fe}(\mathrm{III})$ complexe

\section{Effect of buffer solutions}

The best values of buffer $\mathrm{pH} 13$ recorded for the highest absorbance values were. The absorbance is measured the absorbance results are shown in Table 1 for complexes $(\mathrm{Cu}+$ cefixime). 
Table 1. Buffer $\mathrm{pH} 13$

\begin{tabular}{|c|c|}
\hline Preparation Buffer $\mathrm{pH} \quad 13$ & Absorbance \\
\hline Potassium buffer solutions & 0.469 \\
\hline
\end{tabular}

And the best values of buffer $\mathrm{pH} 11$ recorded for the highest absorbance values were the absorbance is measured. The absorbance results are shown in Table 2 for complexes (Fe+ cefixime).

Table 2. Buffer pH 11

\begin{tabular}{lc}
\hline \multicolumn{1}{c}{ Preparation buffer pH 11 } & Absorbance \\
\hline Sodium bicarbonate buffersolutions & 0.563 \\
Sodium hydrogen ortho phosphate & 0.268 \\
\hline
\end{tabular}

\section{Effect of volumes of buffer solutions}

Figure 6 show the value of absorbance intensity for the complexes drug- $\mathrm{Fe}$ and drug-Cu against the value of buffer solutions, the best values of sodium bicarbonate buffer solutions recorded for the highest absorbance values, the best values of potassium buffer solutions recorded for the highest absorbance values.

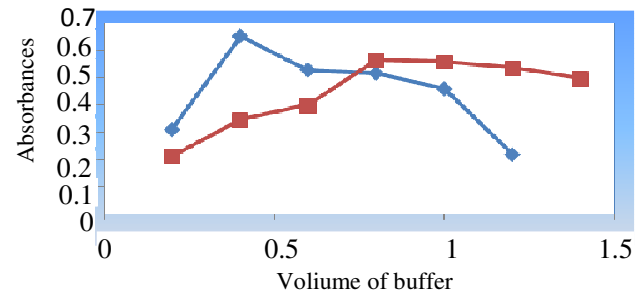

Figure 6. Buffer of pH effect on the absorbance of drug- $\mathrm{Cu}$ (II) and drug- $\mathrm{Fe}(\mathrm{III})$ complexe Effect of type of surfactant with each metal cefixime

The type of surfactant plays very substantial role in cloud point extraction process where each surface owns spectral properties depend on practical basis of Micelles. Aliquots of $10 \mathrm{~mL}$ of a solution contains $1 \mathrm{~mL}$ cefixime, $2 \mathrm{~mL} \mathrm{Cu}, 0.8 \mathrm{~mL}$ buffer $\mathrm{pH} 13$ for copper metal and $1 \mathrm{~mL}$ cefixime, $0.8 \mathrm{~mL} \mathrm{Fe}, 0.4 \mathrm{~mL}$ buffer $\mathrm{pH} 11$ for Iron metal in $10 \mathrm{~mL}$ volumetric flask and used different surfactant for each drug (Tween 20, Tween 80, CTAP, SDS, triton x-100, triton x114) at $50{ }^{\circ} \mathrm{C}$ for $20 \mathrm{~min}$ for cupric incubation time then it centrifugeted at $3000 \mathrm{rpm}$ for 10 min, separated the surfactant- rich phase and dissolved in $1 \mathrm{~mL}$ ethanol then measured by UVVis at $\lambda_{\max }=827 \mathrm{~nm}$ for $\mathrm{Cu}$ and $439 \mathrm{~nm}$ for Fe results shown in.

Table 3. Effect of surfactant type on absorbance

\begin{tabular}{ccccccc}
\hline $\begin{array}{c}\text { Absorbance at } \\
\lambda_{\max }=439 \text { for Fe(III) }\end{array}$ & 0.293 & 0.539 & 0.476 & 0.428 & 0.344 & 0.743 \\
\hline $\begin{array}{c}\text { Absorbance at } \\
\lambda_{\max }=827 \text { for } \mathrm{Cu}(\mathrm{II})\end{array}$ & 0.151 & 0.394 & 0.368 & 0.298 & 0.189 & 0.569 \\
\hline
\end{tabular}

It was observed that triton $\mathrm{x}$ - 114 which have maximum absorbance at $439 \mathrm{~nm}$ is the best one for further study as shown in Table 3. Plotting the absorbance values of the cloud point versus the type of surfactant is shown in Figure $7 \& 8$.

\section{Effect of triton $x$-114 amount}

Most studies confirm that the amount of an non-ionic surfactant type TX-114 as an extracting medium plays an important role for maximizing the extraction efficiency by minimizing the 
phase volume ratio (Vs/Va) and therefore improving the pre-concentration factor of the $\mathrm{CPE}$ procedure. Therefore, the amount of TX-114 was investigated by varying the volume of $10 \% \mathrm{TX}-114$ between $(0.2-2.0 \mathrm{~mL})$ for cefix. The results are presented in Figure 9. It was noticed that the absorbance values of cefix drug continued to increase dramatically and reached maximum at $1.6 \mathrm{~mL}$ of $10 \% \mathrm{TX}-114$ (i.e. $1.6 \% \mathrm{TX}-114$ in $10 \mathrm{~mL}$ solution) for $\mathrm{Cu}$ metal and $1.0 \mathrm{~mL}$ of $10 \% \mathrm{TX}-114$ (i.e. $1.0 \% \mathrm{TX}-114 \mathrm{in} 10 \mathrm{~mL}$ solution) for Fe metal. These values were selected as optimal amount and used in the proposed methods for the detection of cefix, plotting the absorbance values of the cloud point versus the volume of triton $\mathrm{x}-114$ is shown in Figure 9.

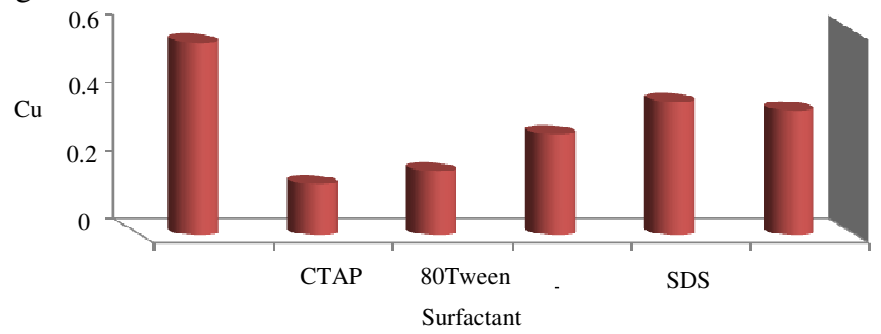

Figure 7. Type of surfactant for $\mathrm{Cu}(\mathrm{II})$

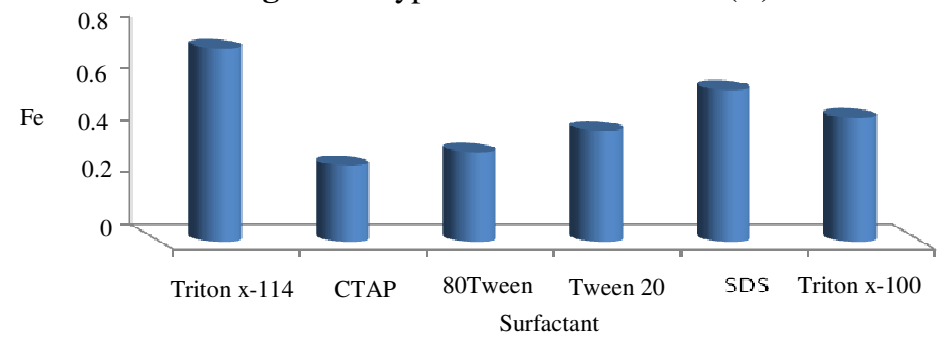

Figure 8. Type of surfactant for Fe(III)

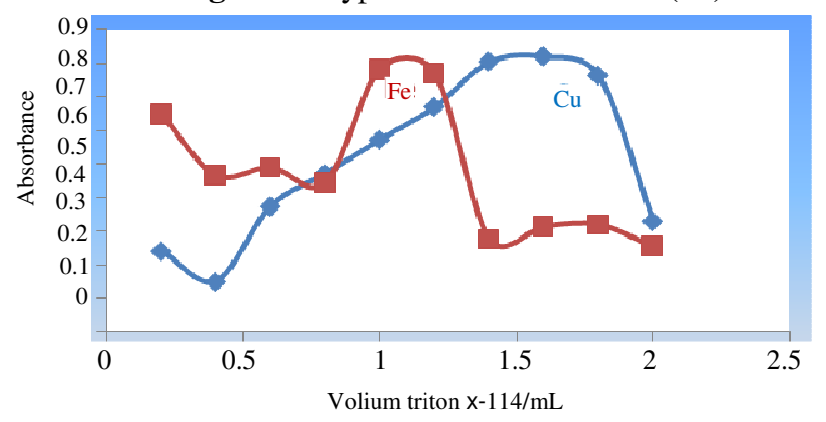

Figure 9. Effect of the TX-114 amount on absorbance of complexes product (Conditions: for cefix: $100 \mu \mathrm{gmL}^{-1}$, metal Cu and metal $\mathrm{Fe}$ )

\section{Effect of equilibration temperature and incubation time}

The influence of these two parameters is considered of the most crucial steps in CPE, in order to ensure the efficient phase separation, which reflects certainly the magnitude of extraction efficiency of each target analyte. Figure 10 shows the variation on the absorption signal via varying the temperature between 35 to $80{ }^{\circ} \mathrm{C}$ at $20 \mathrm{~min}$ for incubation time for drug. 


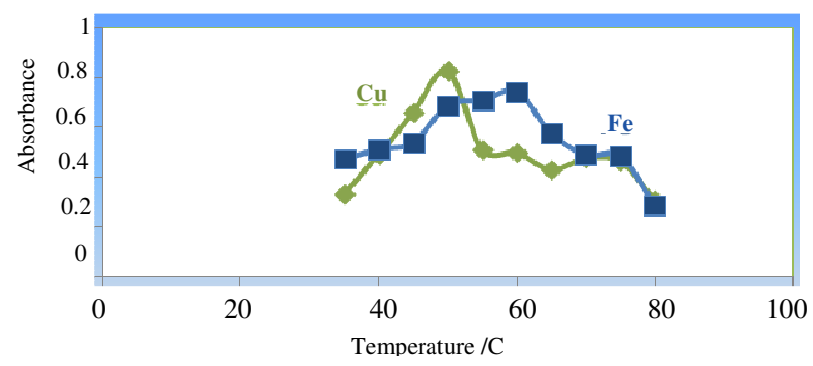

Figure 10. Absorbance versus temperature for $\mathrm{Fe}(\mathrm{III})$ and $\mathrm{Cu}(\mathrm{II})$

The results show that the highest absorbency and extraction efficiency of the drug at temperature at $60{ }^{\circ} \mathrm{C}$ for cefixime with $\mathrm{Fe}(\mathrm{III}), 50{ }^{\circ} \mathrm{C}$ for cefixime with $\mathrm{Cu}(\mathrm{II})$ for $20 \mathrm{~min}$ complexes then decreases in absorbance at higher temperature due to decomposition of product which reduces the extraction efficiency. This temperature is fixed in subsequent experiments.

\section{Effect of the incubation time}

Amount of $10 \mathrm{~mL}$ solution was prepared in volumetric flask containing, for Fe metal ion (1 mL cefixime, $0.8 \mathrm{~mL} \mathrm{Fe}, 0.4 \mathrm{~mL}$ buffer $\mathrm{pH} 11$ and $1 \mathrm{~mL} \mathrm{10 \% (v/v)} \mathrm{triton} \mathrm{x}-114$ ) and for $\mathrm{Cu}$ metal ( $1 \mathrm{~mL}$ cefixime, $2 \mathrm{~mL} \mathrm{Cu}, 0.8 \mathrm{~mL}$ buffer $\mathrm{PH} 13$ and $1.6 \mathrm{~mL} 10 \%$ (v/v) triton $\mathrm{x}$-114) then it was completed to the mark by distilled water, were mixed and the temperature was $60{ }^{\circ} \mathrm{C}$ for $\mathrm{Fe}$ and $50{ }^{\circ} \mathrm{C}$ for $\mathrm{Cu}$ and the incubation time varies from $(5-50)$ min to form cloud point extraction then was measured by UV-Vis at $\lambda_{\max }=439 \mathrm{~nm}$ for Fe and at $\lambda_{\max }=827 \mathrm{~nm}$ for $\mathrm{Cu}$ Figure 11.

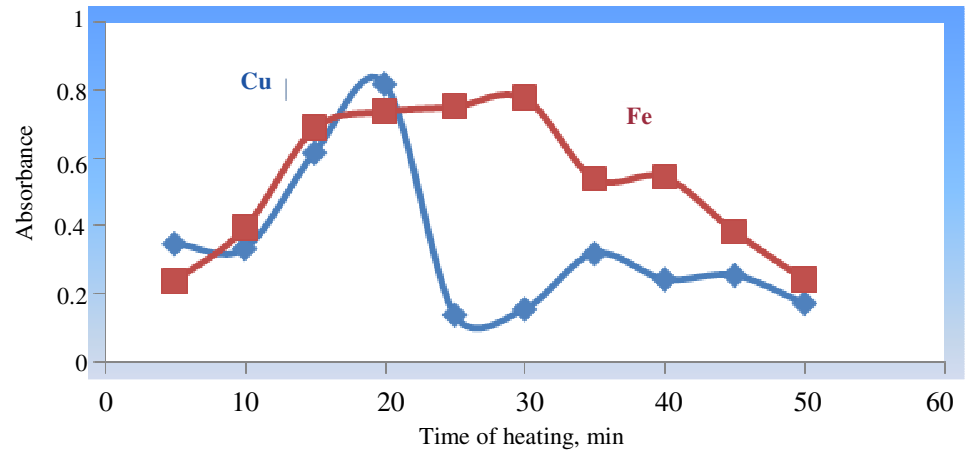

Figure 11. Absorbance versus time for $\mathrm{Cu}$ (II) and for $\mathrm{Fe}(\mathrm{III})$

The time represents the amount of heat accumulated in the solution that allows Micelles lose water molecules in order to give small size hydrophobic with high viscosity easily entrap the product in it. It is clear that the optimum incubation time is $20 \mathrm{~min}$ for $\mathrm{Cu}$ respectively and maximum absorbance for all extracted $\mathrm{Fe}(\mathrm{III})$ complexes were observed after $30 \mathrm{~min}$.

\section{Order of additions}

The effect of order for additions of the metal on the absorbance of each analyte by the general CPE was tested. Figure 12 shows that the best order of addition is the number 4 for target analytes due to giving a highest absorption signal among the others. The absorbance was measured and the absorbance results are shown in Table 4. 
Table 4. Data of absorbance to order additions

\begin{tabular}{cccc}
\hline No & Order additions & $\begin{array}{c}\text { Absorbance at } \lambda_{\max } \\
=439 \text { for Fe(III) }\end{array}$ & $\begin{array}{c}\text { Absorbance at } \lambda_{\max } \\
=827 \text { for } \mathrm{Cu}(\mathrm{II})\end{array}$ \\
\hline 1 & $D+M+B+T$ & 0.767 & 0.824 \\
2 & $M+D+B+T$ & 0.684 & 0.174 \\
3 & $D+B+M+T$ & 0.607 & 0.087 \\
4 & $M+B+D+T$ & 0.732 & 0.788 \\
\hline
\end{tabular}

Plotting of the absorbance values versus the order additions is shown in Figure 12.

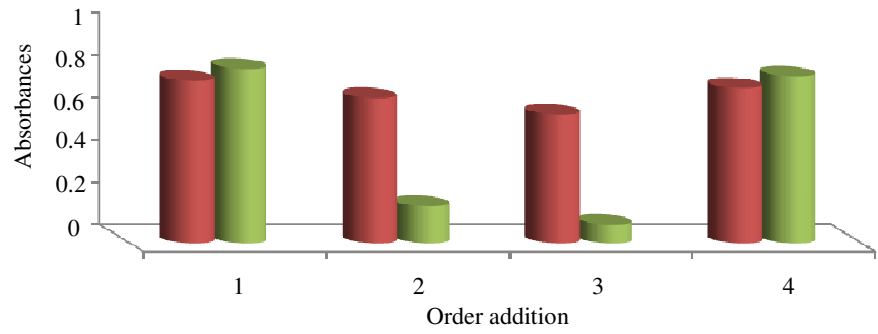

Figure 12. Effect of order additions for $\mathrm{Fe}$ (red) and $\mathrm{Cu}$ (green)

It is noted that the best addition is the first order of $\mathrm{Fe}(\mathrm{III})$ and the best addition is the four order of $\mathrm{Cu}(\mathrm{II})$, because if it's another order gets lost in the intensity of color and this order fixed in subsequent experiment.

\section{Effect of organic solvents}

Different organic solvents were examined to evaluate their effects on the intensity of the resulting complex and the data are shown in Table 5.

Table 5. Data of absorbance to solvents

\begin{tabular}{clcc}
\hline No & \multicolumn{2}{c}{ Solvents } & \multicolumn{2}{c}{ Absorbance at } & \multicolumn{2}{c}{ Absorbance at } \\
& & $\lambda_{\max }=439$ for $\mathrm{Fe}$ & $\lambda_{\max }=827$ for $\mathrm{Cu}$ \\
\hline 1 & Water & 0.771 & 0.823 \\
2 & Ethanol & 0.699 & 0.795 \\
3 & Methanol & 0.623 & 0.363 \\
4 & Acetonitril & 0.544 & 0.685 \\
5 & $\mathrm{H}_{2} \mathrm{O}_{2}$ & 0.377 & 0.210 \\
6 & chloroform & 0.632 & 0.490 \\
7 & Acetyl aceton & 0.105 & 0.203 \\
8 & Dimethyformamide & 0.103 & 0.246 \\
9 & Dimethy phthalate & 0.078 & 0.043 \\
10 & Dimethymalonate & 0.016 & 0.021 \\
\hline
\end{tabular}

Plotting of the absorbance values versus the solvent is shown in Figure 13.

It has been shown that water is the optimum solvent, economically, sensitivity method, cheap price, to provide and nontoxic. This solvent is fixed in subsequent experiment.

\section{Effect of interference}

The effect of some foreign organic compounds and inorganic compounds, which often found in environmental were studied by adding $1 \mathrm{~mL}$ of $(100 \mathrm{ppm})$ equal amounts organic compounds, inorganic compounds to $1 \mathrm{~mL}$ of $(100 \mathrm{ppm})$ of complex. The color was developed following the recommended procedure described earlier. 


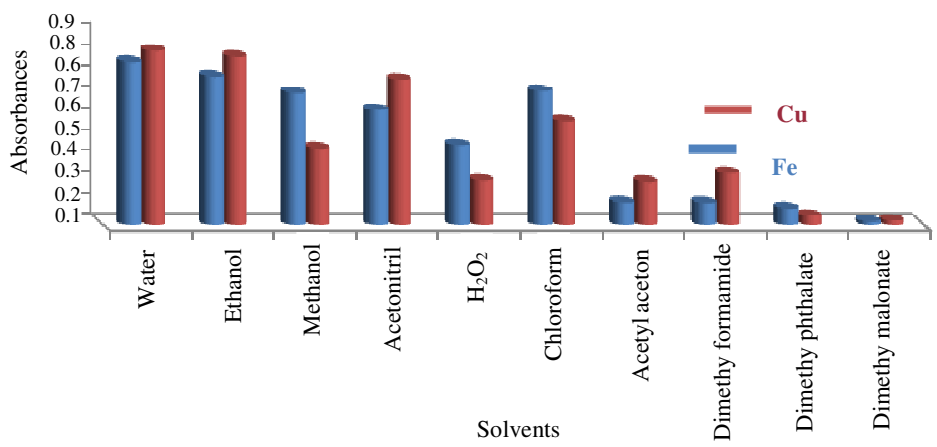

Figure 13. Effect of solvents for $\mathrm{Fe}$ and $\mathrm{Cu}$

Table 6. Effect of interference

\begin{tabular}{|c|c|c|}
\hline 100 ppm Interference & $\begin{array}{c}\text { Absorbance at } \\
\lambda_{\max }=439 \text { for } \mathrm{Fe}\end{array}$ & $\begin{array}{c}\text { Absorbance at } \\
\lambda_{\max }=827 \text { for } \mathrm{Cu}\end{array}$ \\
\hline With out & 0.772 & 0.822 \\
\hline Lactose & 0.196 & 0.547 \\
\hline Starch & 0.568 & 0.556 \\
\hline Arabic Gum & 0.212 & 0.515 \\
\hline Talc & 0.315 & 0.353 \\
\hline Glucose & 0.248 & 0.385 \\
\hline $\mathrm{Ca}_{3}\left(\mathrm{PO}_{4}\right)_{2}$ & 0.201 & 0.202 \\
\hline $\mathrm{CaCO}_{3}$ & 0.011 & 0.236 \\
\hline
\end{tabular}

It was observed from Table 6 were not interfering with the determination at levels found in complex form.

\section{Selected optimum conditions}

After the study of the effect of different physical and chemical conditions on the absorbance intensity of the colored product, the optimum conditions for the proposed procedure were summarized in Table 7 and were used in all subsequent experiments.

Table 7. The optimum conditions for the determination of cefixime

\begin{tabular}{|c|c|c|c|c|}
\hline Optimum & Concentrations & $\begin{array}{l}\text { Range } \\
\text { selected }\end{array}$ & $\begin{array}{l}\text { Optimum } \\
\text { quantities of } \\
\text { complex } \\
\text { (Cefxi-Fe) }\end{array}$ & $\begin{array}{c}\text { Optimum } \\
\text { quantities } \\
\text { of complex } \\
(\mathrm{Cefxi}-\mathrm{Cu})\end{array}$ \\
\hline$\chi_{\max }, \mathrm{nm}$ & - & $190-1100$ & 439 & 827 \\
\hline $\begin{array}{l}\text { Effect of volume of metal } \\
\text { ion required }\end{array}$ & $1000 \mathrm{ppm}$ & $0.2-3.5 \mathrm{~mL}$ & $0.8 \mathrm{~mL}$ & $2 \mathrm{~mL}$ \\
\hline Effect of PH & $0.1 \mathrm{M}(\mathrm{NaOH})$ & $1-14$ & 11 & 13 \\
\hline Buffer $\mathrm{pH}$ & - & - & $\begin{array}{c}\text { Sodium } \\
\text { bicarbonate } \\
\text { buffer solutions }\end{array}$ & $\begin{array}{l}\text { Potassium } \\
\text { buffer } \\
\text { solutions }\end{array}$ \\
\hline Effect of volume of Buffer & - & $0.2-1.6 \mathrm{~mL}$ & $0.6 \mathrm{~mL}$ & $0.8 \mathrm{~mL}$ \\
\hline $\begin{array}{l}\text { Effect of volume of } \\
\text { triton x114 required }\end{array}$ & $10 \%(\mathrm{v} / \mathrm{v})$ & $0.2-2.0 \mathrm{~mL}$ & $1 \mathrm{~mL}$ & $1.6 \mathrm{~mL}$ \\
\hline Effect of time heating & - & $5-60 \mathrm{~min}$ & $30 \mathrm{~min}$ & $20 \mathrm{~min}$ \\
\hline Cefixime solution required & $1000 \mathrm{ppm}$ & $10-160 \mathrm{ppm}$ & $1 \mathrm{~mL}$ & $1 \mathrm{~mL}$ \\
\hline
\end{tabular}




\section{Preparation of calibration curve in $C P E$}

Amount of $10 \mathrm{~mL}$ solution was prepared containing increasing concentration of drug cefixime by taking (10-160) $\mu \mathrm{gmL}^{-1}$ cefixime, $0.8 \mathrm{~mL} \mathrm{Fe}, 0.4 \mathrm{~mL}$ buffer $\mathrm{pH} 11$ and $1 \mathrm{~mL} 10 \%(\mathrm{v} / \mathrm{v})$ triton $\mathrm{x}-114$ and for $\mathrm{Cu}$ metal $2 \mathrm{~mL}$ was taken $0.8 \mathrm{~mL}$ buffer $\mathrm{pH} 13,10$ $130 \mu \mathrm{gmL}^{-1}$ cefixime and $1.6 \mathrm{~mL} 10 \%(\mathrm{v} / \mathrm{v})$ triton $\mathrm{x}-114$ then it was completed to the mark by distilled water and mixed, heated at optimum temperature in the thermostat water bath at optimum incubation time, to form cloud point then aqueous phase was separated by centrifugation at $4000 \mathrm{rpm}$ for $20 \mathrm{~min}, 1 \mathrm{~mL}$ ethanol was added to the surfactant-rich phase to dissolve it then is measured by UV-Vis at $\lambda_{\max }=439 \mathrm{~nm}$ for iron and at $\lambda_{\max }=827 \mathrm{~nm}$ for cupric, triplicate manner. The absorbance measurements are illustrated in Table 8 and Table 9

Table 8. The absorbance measurements of standard solutions of complex (CFX-cu)

\begin{tabular}{ccccc}
\hline Conc. ppm & Mean Absorbance & RSD\% & Found & Recovery, $\%$ \\
\hline 10 & 0.155 & 1.2903 & 13.1184 & 131 \\
20 & 0.219 & 2.7775 & 21.5394 & 107 \\
30 & 0.286 & 0.3496 & 30.3553 & 101 \\
40 & 0.345 & 0.7668 & 38.1184 & 95 \\
50 & 0.417 & 0.4796 & 47.5921 & 95 \\
60 & 0.497 & 0.2012 & 58.1184 & 96 \\
70 & 0.582 & 0.4545 & 69.3026 & 99 \\
80 & 0.661 & 0.1512 & 79.6973 & 99 \\
90 & 0.742 & 0.2695 & 90.355 & 100 \\
100 & 0.823 & 0.7390 & 101.013 & 101 \\
110 & 0.897 & 0.2949 & 110.73 & 100 \\
120 & 0.986 & 0.8049 & 122.46 & 102 \\
130 & 1.034 & 0.5117 & 128.77 & 99 \\
\hline
\end{tabular}

Table 9. The absorbance measurements of standard solutions of complex (CFX-Fe)

\begin{tabular}{ccccc}
\hline Conc. ppm & Mean Absorbance & RSD\% & Found & Recovery, $\%$ \\
\hline 10 & 0.085 & 3.1126 & 9.8732 & 98 \\
20 & 0.152 & 1.3157 & 19.3098 & 96 \\
30 & 0.21 & 1.7169 & 27.478 & 91 \\
40 & 0.301 & 0.3322 & 40.2957 & 100 \\
50 & 0.39 & 0.4441 & 52.8309 & 105 \\
60 & 0.439 & 1.2053 & 59.7323 & 99 \\
70 & 0.497 & 0.2012 & 67.9014 & 97 \\
80 & 0.589 & 0.4491 & 80.859 & 101 \\
90 & 0.671 & 0.2980 & 92.4081 & 102 \\
100 & 0.732 & 0.3614 & 101 & 101 \\
120 & 0.845 & 0.5158 & 116.915 & 97 \\
140 & 1.011 & 0.0989 & 140.295 & 100 \\
160 & 1.143 & 0.0874 & 158.88 & 99 \\
\hline
\end{tabular}

The calibration curve was plotting the mean absorbance values of the cloud point versus the concentration (ppm) of CFX- cupric as shown in Figure 14.

The calibration curve was plotting the mean absorbance values of the cloud point versus the concentration (ppm) of CFX- Iron as shown in Figure 15. 


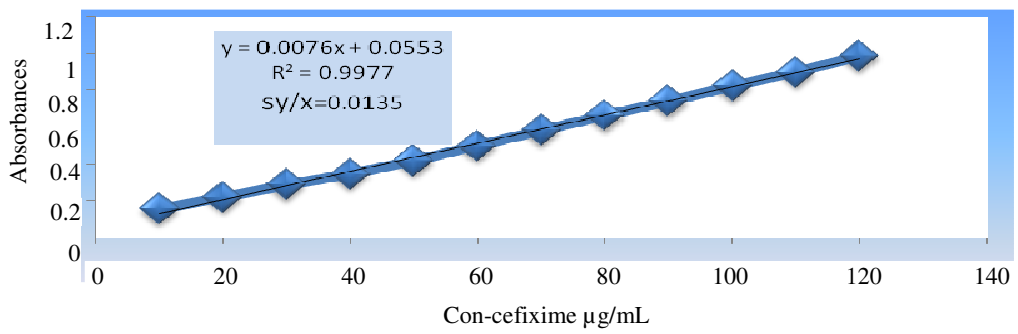

Figure 14. (Cefixime $+\mathrm{Cu}$ ) calibration curve

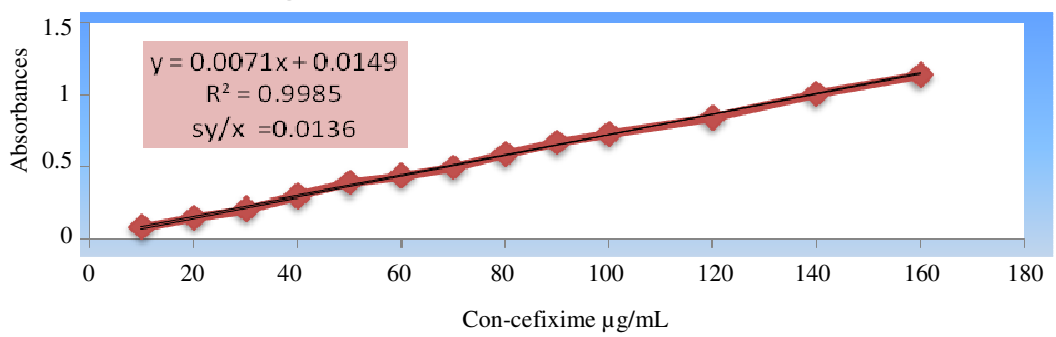

Figure 15. (Cefixime + Fe) calibration curve

\section{Optical characteristics features of the calibration curve}

Table 10 shows the main features of the calibration curve and measuring the absorbance at $827 \mathrm{~nm}$ and $439 \mathrm{~nm}$.

Table 10. Optical characteristic features of calibration curve

\begin{tabular}{|c|c|c|}
\hline Parameter & Complex (cefixime-Fe) & Complex (cefixime-Cu) \\
\hline Color of product & orange & Green \\
\hline Wave length $\lambda_{\max }, \mathrm{nm}$ & 439 & 827 \\
\hline Concentration rang, $\mu \mathrm{gmL}^{-1}$ & $\left(10-160 \mu \mathrm{gmL}^{-1}\right)$ & $\left(10-130 \mu \mathrm{gmL}^{-1}\right)$ \\
\hline Regression equation & $y=0.0071 x+0.0149$ & $y=0.0076 x+0.0553$ \\
\hline Correlation coefficient(r) & 0.9992 & 0.9988 \\
\hline Correlation coefficient $\left(\mathrm{r}^{2}\right)$ & 0.9985 & 0.9977 \\
\hline Variation coefficient, $\%$ & 99.85 & 99.77 \\
\hline Limit of detection, $\mu \mathrm{gmL}^{-1}$ & 1.5865 & 1.6906 \\
\hline Limit of quantitation, $\mu \mathrm{gmL}^{-1}$ & 5.2887 & 5.6355 \\
\hline Sandell's sensitivity, $\mu \mathrm{g} \mathrm{cm}^{-2}$ & 0.2320 & 0.1315 \\
\hline Slope (m) & 0.0071 & 0.0076 \\
\hline Intercept (C) & 0.0149 & 0.0553 \\
\hline Molar absorptivity, L.mol ${ }^{-1} \cdot \mathrm{cm}^{-1}$ & $1.9 \times 10^{2}$ & $3 \times 10^{3}$ \\
\hline Composition of product & $1: 1$ & $1: 1$ \\
\hline C.L for slope $(b \pm t S b)$ at $95 \%$ & $0.0071 \pm 1.8682 \times 10^{-4}$ & $0.0076 \pm 2.42 \times 10^{-3}$ \\
\hline C.L for intercept $(\mathrm{a} \pm \mathrm{tSa})$ at $95 \%$ & $0.0149 \pm 0.016229$ & $0.0553 \pm 1.74739$ \\
\hline C.L for conc. $30 \mu \mathrm{gmL}^{-1}$ at $95 \%$ & $27.478 \pm 2.8 \times 10^{-6}$ & $30.3553 \pm 2.48 \times 10^{-6}$ \\
\hline C.L for conc. $60 \mu \mathrm{gmL}^{-1}$ at $95 \%$ & $59.7323 \pm 4.1 \times 10^{-6}$ & $58.1184 \pm 2.48 \times 10^{-6}$ \\
\hline C.L for conc. $90 \mu \mathrm{gmL}^{-1}$ at $95 \%$ & $92.4081 \pm 4.9 \times 10^{-6}$ & $90.355 \pm 4.96 \times 10^{-6}$ \\
\hline C.L for conc. $120 \mu \mathrm{gmL}^{-1}$ at $95 \%$ & $116.915 \pm 3.4 \times 10^{-5}$ & $122.46 \pm 6.20 \times 10^{-5}$ \\
\hline
\end{tabular}




\section{Stoichiometric determination of color complex}

\section{Continuous variation method (Job's method)}

A series of $1,2,3,4,5,6,7,8$ and $9 \mathrm{~mL}$ of $1 \times 10^{-4} \mathrm{~mol} \mathrm{~L}^{-1}$ of the solution that contain cefixime was ipette into each of $10 \mathrm{~mL}$ volumetric flask then $9,8,7,6,5,4,3,2$ and $1 \mathrm{~mL}$ of $1 \times 10^{-4}$ mol L ${ }^{-1}$ of metal the absorbance of the solution was measured by UV-Vis spectrophotometer at $\lambda_{\max } 827 \mathrm{~nm}$ and $439 \mathrm{~nm}$ the stoichiometric ratio between cefixime with metal 1:1 results are shown in the Table 11.

Table 11. The continuous variation method of cefixime with metal (Copper) complex

\begin{tabular}{ccccc}
\hline V D mL & V M mL & VD / VT & $\begin{array}{c}\text { Absorbance at } \\
\lambda=827 \text { for color } \\
\text { compound }\end{array}$ & $\begin{array}{c}\text { Absorbance at } \\
\lambda=439 \text { for color } \\
\text { compound }\end{array}$ \\
\hline 1 & 9 & 0.1 & 0.142 & 0.067 \\
2 & 8 & 0.2 & 0.313 & 0.159 \\
3 & 7 & 0.3 & 0.431 & 0.290 \\
4 & 6 & 0.4 & 0.549 & 0.357 \\
5 & 5 & 0.5 & 0.643 & 0.519 \\
6 & 4 & 0.6 & 0.52 & 0.479 \\
7 & 3 & 0.7 & 0.356 & 0.278 \\
8 & 2 & 0.8 & 0.121 & 0.140 \\
9 & 1 & 0.9 & 0.034 & 0.032 \\
\hline
\end{tabular}

Plotting the value of absorbance versus the VD/VT is shown in Figure 16

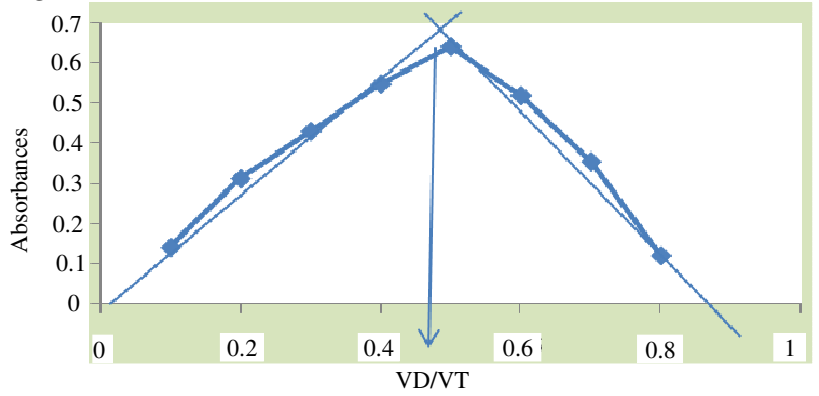

Figure 16. Continuous variation method plot

VD: values of the compound (Cefixime), V M: The values of the metal (Copper). VT: Total (V M+V D)

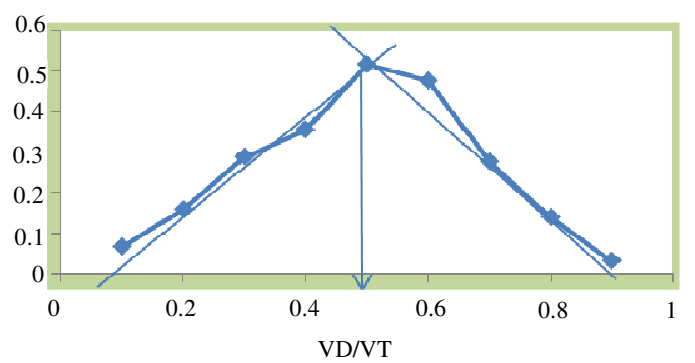

Figure 17: Continuous variation method plot

VD: values of the compound (Cefixime), V M: The values of the metal (Iron). VT: Total (V M+V D) 


\section{Mole-Ratio method}

Aliquots of $10 \mathrm{~mL}$ solution containing $1 \times 10^{-4} \mathrm{~mol} \mathrm{~L}^{-1}$ of $1 \mathrm{~mL}$ cefixime and increasing concentrations $1 \times 10^{-4} \mathrm{~mol} \mathrm{~L}^{-1}$ of $0.2,0.4,0.6,0.8,1.0,1.2,1.4,1.6$ and $1.8 \mathrm{~mL}$ of $\mathrm{Cu}$ and $\mathrm{Fe}$ $2 \times 10^{-6}-2 \times 10^{-5}$ mol L ${ }^{-1}$ metal. The absorbance of the solutions were measured by UV-Vis spectrophotometer versus blank at $\lambda_{\max }=827$ and $439 \mathrm{~nm}$ the stoichiometric ratio between 1:1 results are shown in the Table 12.

Table 12. The mole-ratio method of the cefixime with copper and iron

\begin{tabular}{cccc}
\hline CL & CL/CM & $\begin{array}{c}\text { Absorbance at } \\
\lambda=827 \mathrm{~nm}\end{array}$ & $\begin{array}{c}\text { Absorbance at } \\
\lambda=439 \mathrm{~nm} \text { for color compound }\end{array}$ \\
\hline $2 \times 10^{-6}$ & 0.2 & 0.032 & 0.098 \\
$4 \times 10^{-6}$ & 0.4 & 0.094 & 0.149 \\
$6 \times 10^{-6}$ & 0.6 & 0.121 & 0.192 \\
$8 \times 10^{-6}$ & 0.8 & 0.153 & 0.231 \\
$1 \times 10^{-5}$ & 1.0 & 0.201 & 0.248 \\
$1.2 \times 10^{-5}$ & 1.2 & 0.194 & 0.241 \\
$1.4 \times 10^{-5}$ & 1.4 & 0.199 & 0.235 \\
$1.6 \times 10^{-5}$ & 1.6 & 0.195 & 0.229 \\
$1.8 \times 10^{-5}$ & 1.8 & 0.199 & 0.218 \\
\hline
\end{tabular}

Plotting the value of absorbance versus the CL/CM is shown in Figure 18.

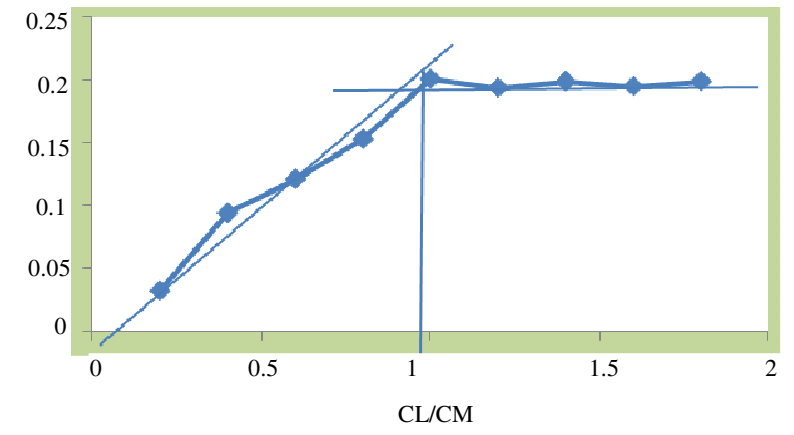

Figure 18. Mole - Ratio plot of cefixime and copper complex

CL: concentration of the metal (Copper), CM: concentration of the compound (Cefixime)

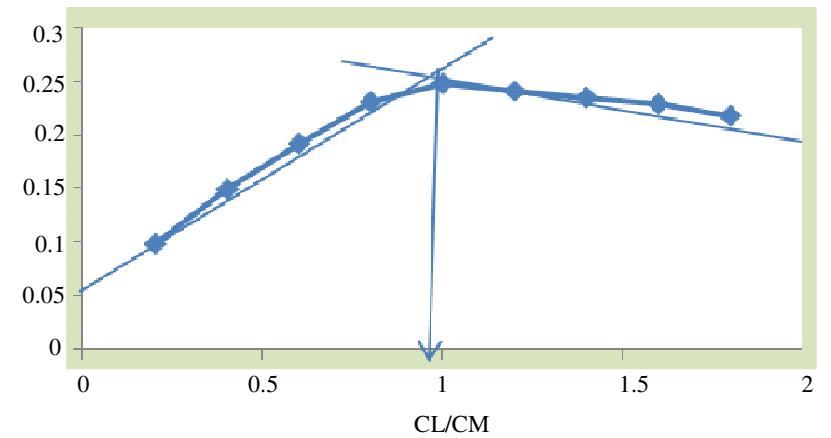

Figure 19. Mole-ratio plot of cefixime and iron complex

CL: concentration of the metal (Iron), CM: concentration of the compound (Cefixime) 


\section{Applications of the cloud point extraction on pharmaceuticals}

CPE has been applied on pharmaceutical cefixime, the manufacture company (Novartis) that contains $(533.9 \mathrm{mg})$ from cefixime. The results are good and of high reliability in the analysis of samples in the pharmaceutical preparation. The results are summarized in the Table 13 for cefixi.

Table 13. Data for determination cefix with cupric in the pharmaceutical preparation capsule (cefixime) by CPE

\begin{tabular}{cccccccc}
\hline $\begin{array}{c}\text { Amount of } \\
\text { cefix/ } \mu \mathrm{gg} \\
\mathrm{mL}^{-1}\end{array}$ & $\begin{array}{c}\text { Mean } \\
\text { absorbance }\end{array}$ & $\begin{array}{c}\text { Relative stander } \\
\text { deviation } \\
\text { (RSD) }\end{array}$ & *Found & $\begin{array}{c}\text { Recovery } \\
\%\end{array}$ & $\begin{array}{c}\text { Average } \\
\text { Recovery\% }\end{array}$ & $\begin{array}{c}\text { Erel } \\
\%\end{array}$ & $\begin{array}{c}\text { Average } \\
\text { Erel\% }\end{array}$ \\
\hline 30 & 0.263 & 0.3802 & 27.32 & 91.0 & & -8.9 & \\
60 & 0.487 & 0.4106 & 56.80 & 94.6 & 90.8 & -5.3 & -9.03 \\
90 & 0.651 & 0.1536 & 78.38 & 87.0 & & -12.9 & \\
\hline \multicolumn{7}{c}{$[*]=$ Average of three } \\
\hline
\end{tabular}

The proposed method is also applied on syrup cefixime the manufacture company is Novartis. As each $(5 \mathrm{~mL})$ from drug contains $(100 \mathrm{mg})$ cefixime, we get good and high reliability results that are summarized in the Tables 14-16 for cefix by CPE.

Table 14. Data for determination cefix with cupric in the pharmaceutical preparation syrup (cefixime) by CPE

\begin{tabular}{cccccccc}
\hline $\begin{array}{c}\text { Amount } \\
\text { of cefix/ } \\
\mu \mathrm{gmL}^{-1}\end{array}$ & $\begin{array}{c}\text { Mean } \\
\text { absorbance }\end{array}$ & $\begin{array}{c}\text { Relative } \\
\text { stander } \\
\text { deviation } \\
\text { (RSD) }\end{array}$ & *Found & Recovery\% & $\begin{array}{c}\text { Average } \\
\text { Recovery\% }\end{array}$ & Erel\% & $\begin{array}{c}\text { Average } \\
\text { Erel\% }\end{array}$ \\
\hline 30 & 0.270 & 0.3703 & 28.25 & 94.1 & & -5.8 & \\
60 & 0.479 & 0.3615 & 55.75 & 92.9 & 93.8 & -7.0 & -6.06 \\
90 & 0.702 & 0.3768 & 85.09 & 94.5 & & -5.4 & \\
\hline
\end{tabular}

Table 15. Data for determination cefix with Iron in the pharmaceutical preparation capsule (cefixime) by CPE

\begin{tabular}{cccccccc}
\hline $\begin{array}{c}\text { Amount } \\
\text { of cefix/ } \\
\mu \mathrm{gmL}^{-1}\end{array}$ & $\begin{array}{c}\text { Mean } \\
\text { absorbance }\end{array}$ & $\begin{array}{c}\text { Relative } \\
\text { stander } \\
\text { deviation } \\
\text { (RSD) }\end{array}$ & *Found & Recovery\% & $\begin{array}{c}\text { Average } \\
\text { recovery\% }\end{array}$ & Erel\% & $\begin{array}{c}\text { Average } \\
\text { erel\% }\end{array}$ \\
\hline 30 & 0.215 & 1.2305 & 28.18 & 93.9 & 97.6 & -0.6 & \\
60 & 0.430 & 0.2325 & 58.46 & 97.4 & & -2.5 & -6.8 \\
90 & 0.665 & 0.2604 & 91.56 & 101.7 & & 1.7 & \\
\hline
\end{tabular}

Table 16. Data for determination cefix with iron in the pharmaceutical preparation syrup (cefixime) by CPE

\begin{tabular}{cccccccc}
\hline $\begin{array}{c}\text { Amount } \\
\text { of cefix/ } \\
\mu \mathrm{g} \mathrm{mL} \mathrm{mL}^{-1}\end{array}$ & $\begin{array}{c}\text { Mean } \\
\text { absorbance }\end{array}$ & $\begin{array}{c}\text { Relative } \\
\text { stander } \\
\text { deviation } \\
\text { (RSD) }\end{array}$ & *Found Recovery\% & $\begin{array}{c}\text { Average } \\
\text { recovery\% }\end{array}$ & Erel\% & $\begin{array}{c}\text { Average } \\
\text { erel\% }\end{array}$ \\
\hline 30 & 0.210 & 0.9523 & 27.47 & 91.5 & 94.0 & -8.4 & \\
60 & 0.394 & 0.2538 & 53.39 & 88.9 & & -11.0 & -5.1 \\
90 & 0.680 & 0.3890 & 93.67 & 104.0 & & 4.0 & \\
\hline
\end{tabular}




\section{Conclusion}

The proposed method is simple, sensitive and free from drastic experimental conditions such as heating. It is also accurate, precise enough to be successfully adopted as an alternative to the existing spectrophotometric method and evaluation of cefixime in a metal Using CPE and in pharmaceutical Preparation samples.

\section{References}

1. Nishant A D, Uttam P S, Rupak K R and Singh G N, J Pharma Anal., 2016, 6, 207213

2. Elham G, Behnaz R, Samaneh A, Alireza V and Vahid R, Pharm Sci., 2015, 21, 136144; DOI:10.15171/PS.2015.28

3. Abdul A R, Hasna M L and Marw A D, Int J Pharmacy Pharma Sci., ISSN- 09751491. 2013, 5(1), 428-433.

4. Suddhasattya D, Prasanna K P, Upadhayay1 U M, Shreya S and Kuntal G, J Pharma Res., 2012, 5(12), 5419-5422.

5. Arora S C, Sharma P K, Irchhaiya R, Khatkar A, Singh N and Gagoria J, Int J Drug Develop Res., 2010, 1(2), 221-228.

6. Meng F, Chen X, Zeng Y and Zhong D, J Chromatogr B Analyt Technol Biomed Life Sci., 2005, 819(2), 277-282; DOI:10.1016/j.jchromb.2005.02.015

7. Raj K A, Yada D, Yada D, Prabu C and Manikantan S, Int J ChemTech Res., 2010, 2(1), 334-336.

8. Zendelovska D, Stafilov T and Milosevski P, Bull Chem Technol Macedonia 2003, 22, 39-45.

9. Adam E H, Saeed A E and Barakat I E, Int J Pharm Sci Res., 2012, 3, 469-473.

10. Kathiresan K, Murugan R, Hameed M S, Gokula K I and Taranath K, Rasayan J Chem., 2009, 2(3), 588-592.

11. Deshpandea M M, Kastureb V S and Gosavib S A, Eurasian J Anal Chem., 2010, 5(3), 227-238.

12. Khandagle K S, Gandhi SV, Deshpande P B, Kale A N and Deshmukh P R, J Chem Pharm Res., 2010, 2(5), 92-96.

13. Shah V and Raj H, Int J Pharm Sci Res., 2012, 3, 1753-1760.

14. Azhagesh Raj K, Int J ChemTech Res., 2010, 2(1), 337-340.

16. Saadiyah A D and Sana R B, ESAIJ, 2015, 10(4), 150-160.

17. Saadiyah A D and Sana R B, Asian J Chem., 2014, 26(24). 